\title{
PENINGKATAN KOMPETENSI GURU DALAM MENYUSUN RENCANA PELAKSANAAN PEMBELAJARAN MELALUI SUPERVISI DAN PENDAMPINGAN INTENSIF
}

\author{
FAIZIN \\ SMP Negeri 1 Tanggungharjo Kabupaten Grobogan \\ Email : faizinabi248@gmail.com
}

\begin{abstract}
ABSTRAK
Kompetensi guru merupakan suatu pernyataan tentang kriteria dalam bentuk pengusaan seperangkat kemampuan pengetahuan, sikap, nilai dan keterampilan bagi seorang Pendidik. Guru diharapkan memiliki kompetensi sesuai dengan Standart yang ditentukan yaitu: 1) pengelolaan pembelajaran, 2) pengembangan profesi, dan 3) penguasaan akademik. Keberhasilan pengelolaan pembelajaran salah satunya ditentukan oleh kompentensi guru dalam menyusun Rencana Pelaksanaan Pembelajaran (RPP). Hasil supervisi perangkat maupun supervisi akademik sebelum penelitian menunjukkan bahwa kompetensi Guru, terutama dalam menyusun RPP belum sesuai dengan kriteria penyusunan RPP yang baik. Hal ini berdampak negatif pada proses pembelajaran dan hasil belajar yang akan dicapai. Sekolah sebagai tempat penyelenggaraan pendidikan dan pembelajaran perlu melakukan upaya untuk meningkatkan kompetensi Guru dalam perencanaan pembelajaran. Upaya yang ditempuh Peneliti sebagai kepala sekolah adalah melaksanakan kegiatan supervisi dan pendampingan intensif secara kontinu. Oleh karena itu Peneliti melaksanakan Penelitian Tindakan Sekolah (PTS) yang bertujuan untuk mengetahui peningkatan kompetensi guru dalam menyususun RPP melalui supervisi dan pendampingan intensif. PTS dilaksanakan sebanyak dua siklus. Alur setiap siklus meliputi: perencaan tindakan, pelaksanaan, pengamatan, analisa hasil dan refleksi. Kondisi awal penelitian berdasarkan supervisi perangkat menunjukkan bahwa nilai rata-rata kesesuaian dengan komponen RPP yang benar sebesar 52\%. Hasil kompetensi Guru dalam menyusun RPP setelah penelitian dilaksanakan pada Siklus I diperoleh nilai rata-rata kesesuaian dengan komponen RPP sebesar 69\%. Pada Siklus II nilai rata-rata kesesuaian dengan komponen RPP meningkat menjadi 83\%. Hasil Supervisi akademis Siklus I diperoleh prosentase ketercapaian sebesar 56\% dan Siklus II meningkat menjadi 85\%. Dengan demikian supervisi dan pendampingan intensif dapat meningkatkan kompetensi Guru dalam menyusun Rencana Pelaksanaan Pembelajaran.
\end{abstract}

Kata Kunci: RPP, Supervisi, Pendampingan Intensif.

\section{ABSTRACT}

Teacher competence is a statement of criteria in the form of mastery of a set of knowledge abilities, attitudes, values and skills for an educator. Teachers are expected to have competencies in accordance with the specified standards, namely: 1) learning management, 2) professional development, and 3) academic mastery. One of the successes of learning management is determined by the competence of the teacher in preparing the Learning Implementation Plan (RPP). The results of device supervision and academic supervision before the study showed that the competence of teachers, especially in preparing lesson plans was not in accordance with the criteria for preparing good lesson plans. This has a negative impact on the learning process and learning outcomes to be achieved. Schools as places for education and learning need to make efforts to improve teacher competence in learning planning. Efforts taken by researchers as school principals are to carry out continuous intensive supervision and assistance activities. Therefore, researchers carry out School Action Research (PTS) which aims to determine the increase in teacher competence in preparing lesson plans through supervision and intensive mentoring. PTS was carried out in two cycles. The flow of each cycle includes: action planning, implementation, observation, analysis of results and reflection. The initial conditions of the study based on device supervision showed that the average value of 
conformity with the correct RPP components was $52 \%$. The results of the teacher's competence in preparing lesson plans after the research was carried out in Cycle I obtained an average value of conformity with the RPP components of $69 \%$. In Cycle II, the average value of conformity with the RPP components increased to $83 \%$. The results of the academic supervision of Cycle I obtained the percentage of achievement of $56 \%$ and Cycle II increased to $85 \%$. Thus, intensive supervision and mentoring can improve the competence of teachers in preparing lesson plans. Keywords: RPP, Supervision, Intensive Mentoring.

\section{PENDAHULUAN}

Pendidik adalah tenaga kependidikan yang berkualifikasi sebagai guru, dosen, konselor, pamong belajar, widyaiswara, tutor, instruktur, fasilitator, dan sebutan lain yang sesuai dengan kekhususannya, serta berpartisipasi dalam menyelenggarakan pendidikan (Sisdiknas, 2003). Selanjutnya dalam UU Guru dan Dosen Republik Indonesia No.14 Tahun 2005 menyebutkan bahwa Guru adalah pendidik profesional dengan tugas utama mendidik, mengajar, membimbing, mengarahkan, melatih, menilai, dan mengevaluasi peserta didik pada pendidikan anak usia dini jalur pendidikan formal, pendidikan dasar, dan pendidikan menengah. Hal ini mengandung maksud bahwa Guru wajib memiliki kualifikasi akademik dan kompetensi untuk mewujudkan tujuan pendidikan yang bermuara pada tercapainya tujuan Pendidikan Nasional nasional. Adapun tujuan pendidikan nasional yang termuat dalam dalam Undang-Undang Nomor 20 Tahun 2003 disebutkan bahwa:

Tujuan pendidikan nasional di Indonesia adalah mengembangkan kemampuan dan membentuk watak serta peradaban bangsa yang bermartabat dalam rangka mencerdaskan kehidupan bangsa, bertujuan untuk berkembangnya potensi peserta didik agar menjadi manusia yang beriman dan bertakwa kepada Tuhan Yang Maha Esa, berakhlak mulia, sehat, berilmu, cakap, kreatif, mandiri, dan menjadi warga negara yang demokratis serta bertanggung jawab.

Keberhasilan pendidikan ditentukan oleh kinerja Guru yang baik. Usaha-usaha untuk mempersiapkan guru menjadi profesional telah banyak dilakukan pemangku kebijakan. Menurut Pidata (1992:3) proses pengembangan kinerja guru terbentuk dan terjadi dalam kegiatan belajar mengajar di tempat mereka bekerja. Selanjutnya Direktorat Pembinaan SMA (2008:3) menyatakan bahwa guru harus mempersiapkan perencanaan pembelajaran dan segala sesuatu agar proses pembelajaran efektif. Perencanaan pembelajaran merupakan langkah yang sangat penting sebelum pelaksanaan pembelajaran. Perencanaan yang matang diperlukan supaya pelaksanaan pembelajaran berjalan secara efektif. Perencanaan pembelajaran dituangkan ke dalam Rencana Pelaksanaan Pembelajaran (RPP). RPP memuat KI, KD, indikator yang akan dicapai, materi yang akan dipelajari, metode pembelajaran, langkah pembelajaran, media pembelajaran, dan sumber belajar serta penilaian. Guru harus mampu berperan sebagai desainer (perencana), implementor (pelaksana), dan evaluator (penilai) kegiatan pembelajaran. Mampu melaksanakan tugas dan fungsinya secara optimal dan profesional. Tupoksi Guru yang dimaksud bertitik tolak dari Peraturan Pemerintah Nomor 19 Tahun 2005 tentang 8 Standar Nasional Pendidikan menyatakan standar proses merupakan salah satu SNP untuk satuan pendidikan dasar dan menengah yang mencakup: 1) Perencanaan proses pembelajaran, 2) Pelaksanaan proses pembelajaran, 3) Penilaian hasil pembelajaran, 4) dan pengawasan proses pembelajaran. Perencanaan pembelajaran meliputi Silabus dan Rencana Pelaksanaan Pembelajaran (RPP).

Kondisi nyata yang terjadi di sekolah peneliti bekerja yang ditugaskan menjadi kepala sekolah di SMP Negeri 3 Tegowanu Grobogan yaitu sebagian besar Guru belum menyususn RPP sesuai dengan komponen RPP yang berlaku. Bahkan masih terdapat beberapa Guru yang belum membuat perencanaan pembelajaran, pada saat melaksanakan kegiatan pembelajaran di kelas. Produk RPP yang disusun oleh Guru sebagian besar produk MGMP atau sumber lain yang belum di revisi atau dikaji untuk disesuaikan dengan kondisi sekolah tempat Guru mengajar. Kondisi yang demikian tentunya berdampak negatif terhadap proses dan hasil belajar 
yang dicapai yaitu tidak tercapainya tujuan pembelajaran yang diharapkan. Dampak negatif pembelajaran ini menjadi permasalahan yang harus segera diselesaikan supaya tidak menjadi penyebab kegagalan untuk mewujudkan tujuan pendidikan sekolah dan tujuan pendidikan nasional. Menurut Pidarta (1992:3) menyatakan bahwa kinerja guru dipengaruhi oleh hasil pembinaan dan supervisi kepala sekolah. Selanjunya sesuai dengan Tupoksi peneliti sebagai kepala sekolah berdasarkan Permendiknas No.13 Tahun 2007 tentang enam standar kompetensi kepala sekolah salah satunya adalah supervisi akademik yaitu membina guru. Beberapa hasil penelitian tentang supervisi antara lain : 1) Penelitian Tindakan Sekolah yang dilakukan oleh Syamsudin (2019) menunjukkan bahwa penerapan supervisi akademik secara efektif dapat meningkatkan kinerja guru. 2) Penelitian yang dilakukan oleh Erni (2017) menunjukkan bahwa semakin baik supervisi akademik kepala sekolah dan semakin baik profesionalisme guru maka semakin baik mutu pendidikan. 3) Penelitian yang dilaksanakan oleh Ali (2017) menunjukkan bahwa supervisi akademik kepala sekolah dapat meningkatkan Kompetensi Guru dalam menyusun Rencana Pelaksanaa Pembelajaran.

Kegiatan Penelitian bertujuan untuk mengetahui peningkatan kompetensi guru dalam menyususun RPP melalui supervisi dan pendampingan intensif. Hal ini didasarkan pada kondisi nyata yang terjadi di sekolah peneliti bekerja sebagian besar Guru belum menyususn RPP sesuai dengan komponen RPP yang berlaku. Hal ini berdampak negatif pada proses pembelajaran dan hasil belajar yang akan dicapai. Sekolah sebagai tempat penyelenggaraan pendidikan dan pembelajaran perlu melakukan upaya untuk meningkatkan kompetensi Guru dalam perencanaan pembelajaran. Permasalahan yang muncul adalah apakah supervisi dan pendampingan intensif dapat meningkatkan kompetensi Guru dalam menyusun RPP ?

Dari uraian di atas juga berdasarkan beberapa pendapat ahli, Peraturan Perundangan yang berlaku dan beberapa hasil penelitian, maka peneliti akan melaksanakan supervisi dan pendampingan intensif terhadap guru SMP Negeri 3 Tegowanu sebagai upaya untuk meningkatkan kompetensi guru dalam menyusun RPP.

\section{METODE PENELITIAN}

Penelitian ini dilakukan dengan metode tindakan sekolah yang berlangsung selama 2 siklus. Masing-masing siklus terdiri dari tahapan perencanaan, pelaksanaan, pengamatan (observasi) dan refleksi. Metode penelitian yang dilakukan peneliti adalah dengan melaksanakan supervisi akademik dan pendampingan intensif baik secara individu maupun kelompok.

Penelitian Tindakan Sekolah dilaksanakan di SMP Negeri 3 Tegowanu Grobogan. Banyaknya Subyek penelitian adalah 11 Guru, waktu pelaksanaan dilakukan pada semester genap dengan 2 kali siklus, yaitu siklus 1 dari bulan Januari - Maret dan siklus ke 2 pada bulan April - Juni 2019. Dengan melaksanakan supervisi akademik dan pendampingan intensif diharapkan mampu meningkatkan kompetensi guru dalam menyusun RPP. Adapun alur PTS dapat dilihat pada gambar 1 berikut ini. 


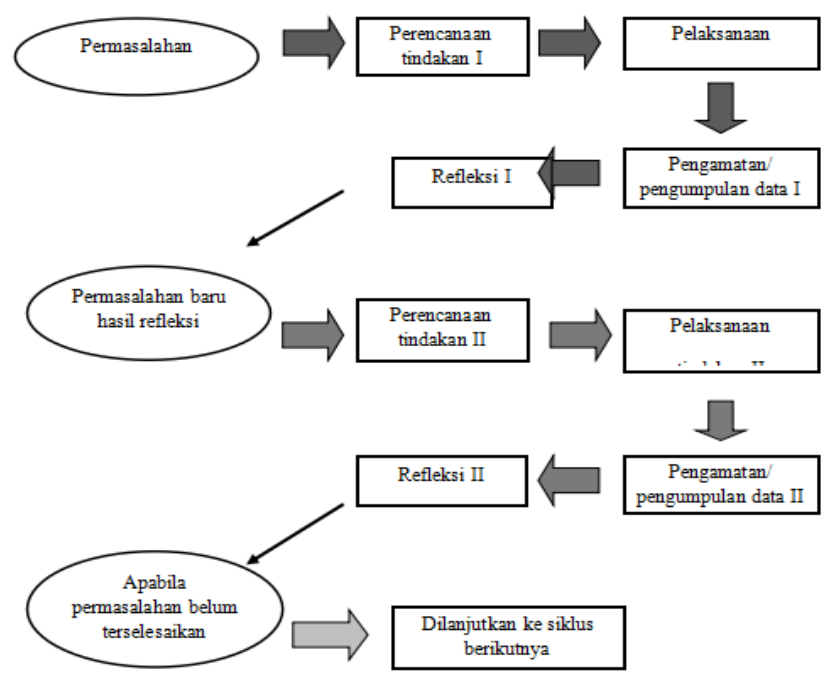

Gambar 1. Alur Penelitian Tindakan Sekolah

Data yang diperlukan dalam penelitian ini diperoleh melalui wawancara dan observasi. Instrumen penelitian sebagai alat pengumpulan data terdiri dari: 1) lembar panduan wawancara, 2) Instrumen supervisi RPP, 3) instrumen supervisi akademik atau supervisi kunjungan kelas.

Data yang sudah diperoleh kemudian dianalisa. Teknik analisis data pada penelitian ini dilakukan secara kuantitatif dan kualitatif. Data hasil wawancara dan pengamatan dianalisis secara kuantitatif berdasarkan persentase dan ditabulasikan dalam data kualitatif sesuai dengan kategori yang digunakan.

Hasil analisa data selanjutnya digunakan untuk menentukan keberhasilan penelitian. Penelitian dilakukan secara berulang dan berkelanjutan sampai tujuan penelitian tercapai. Penelitian ini dikatakan dapat mencapai tujuan apabila terpenuhi indikator yang ditentukan yaitu: 1) 100\% guru menyusun RPP sesuai dengan komponen-komponen RPP yang ditentukan, 2) RPP yang dibuat oleh Guru minimal dalam kategori baik yaitu Prosentase skor total ketercapaian komponen-komponen RPP minimal 80\%, dan 3) Untuk semua komponenkomponen RPP minimal dalam kategori baik.

\section{HASIL DAN PEMBAHASAN}

Penelitian ini diawali dengan wawancara. Materi wawancara yang ditanyakan terkait dengan pengetahuan Guru tentang dasar hukum atau pedoman penyusunan RPP dan komponenkomponen RPP. Wawancara yang dilaksanakan Peneliti juga berkaitan dengan sumber RPP yang dibuat oleh guru yaitu RPP buatan sendiri atau pihak lain, RPP hasil dari MGMP, RPP disusun dengan mengadopsi dan melakukan revisi sesuai dengan tempat Guru mengajar. Kegiatan penelitian dilanjutkan dengan sosialisasi, supervisi perangkat RPP dan supervisi kunjungan kelas (akademik). Hasil wawancara awal penelitian, hasil supervisi dari siklus I dan siklus II dan pembahasan hasil penelitian diuraikan berikut ini.

\section{Hasil}

Hasil wawancara Peneliti dengan Guru dapat dilihat pada Tabel 1 berikut ini.

Tabel 1. Rekapitulasi hasil wawancara pengetahuan Guru tentang RPP

\begin{tabular}{cccc}
\hline \multirow{2}{*}{ No. } & Materi Wawancara & \multicolumn{2}{c}{ Banyak Guru yang menjawab } \\
& Ya & Tidak \\
\hline \hline 1 & Mengetahui Pedoman RPP & - & 11
\end{tabular}


2 Mengetahui komponen-komponen

RPP

1

3 RPP disusun sendiri

29

4 RPP dari MGMP

$8-3$

$5 \quad$ RPP diadopsi dan direvisi

110

Hasil supervisi perangkat RPP Siklus I dan Siklus II dapat dilihat pada Tabel 2 berikut ini.

Tabel 2. Rekapitulasi hasil supervisi RPP untuk setiap komponen

\begin{tabular}{rlcccccc}
\hline \multirow{2}{*}{ No. } & \multirow{2}{*}{ Komponen-Komponen RPP } & \multicolumn{2}{c}{ Kondisi Awal } & \multicolumn{2}{c}{ Siklus I } & \multicolumn{2}{c}{ Siklus II } \\
& & Jml Skor & $\%$ & Jml Skor & $\%$ & Jml Skor & $\%$ \\
\hline \hline 1 & Identitas mata pelajaran & 30 & 68 & 35 & 80 & 44 & 100 \\
2 & Standar kompetensi & 31 & 70 & 38 & 86 & 42 & 95 \\
3 & Kompetensi dasar & 29 & 66 & 38 & 86 & 42 & 95 \\
4 & Indikator & 18 & 41 & 27 & 61 & 34 & 77 \\
5 & Tujuan pembelajaran & 20 & 45 & 29 & 66 & 36 & 82 \\
6 & Materi ajar & 21 & 48 & 25 & 57 & 35 & 80 \\
7 & Alokasi waktu & 24 & 55 & 33 & 75 & 41 & 93 \\
8 & Metode pembelajaran, & 23 & 52 & 32 & 73 & 33 & 75 \\
9 & Langkah-langkah pembelajaran & 17 & 39 & 23 & 52 & 32 & 73 \\
10 & Sumber belajar & 21 & 48 & 30 & 68 & 31 & 70 \\
11 & Penilaiaan hasil belajar & 18 & 41 & 26 & 59 & 34 & 77 \\
\hline & Total Skor & 252 & & 336 & & 404 & \\
\hline & Prosentase Ketercapaian $(\%)$ & 52 & & 69 & & 83 & \\
\hline
\end{tabular}

Hasil perolehan setiap skor dan prosentase ketercapaian untuk semua komponen RPP dapat dilihat pada Grafik 2 berikut ini.

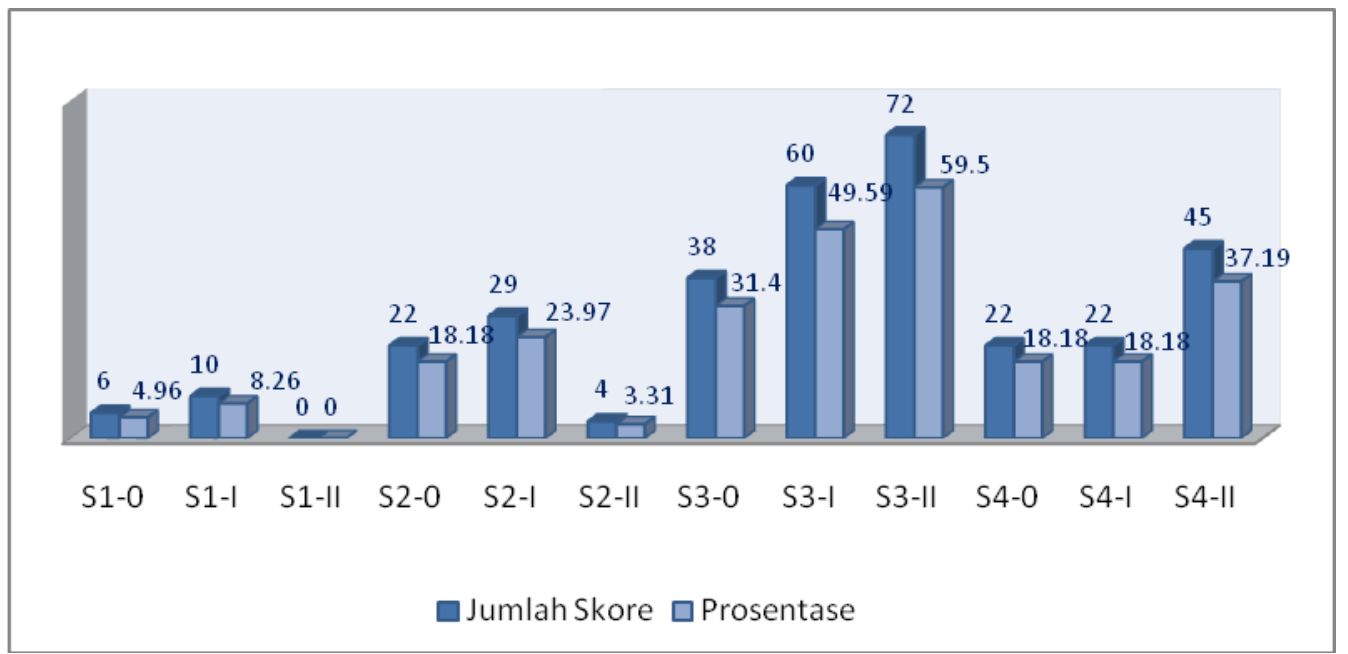

\section{Gambar 2. Grafik Skor ketercapaian hasil supervisi RPP untuk semua komponen}

Hasil supervisi akademik atau supervisi pelaksanaan pembelajaran.

Data yang diperoleh melalui supervisi akademik disajikan dalam bentuk tabel dan grafik. Penyajian data ini bertujuan untuk memudahkan analisa hasil supervisi. Hasil analisa digunakan sebagai dasar evaluasi proses pembelajaran dan umpan balik. Guru menindaklanjuti hasil supervisi untuk melakukan perbaikan penyusunan RPP pada pelaksanaan pembelajaran berikutnya. Data yang dianalisa meliputi hasil supervisi akademik setiap aspek dan hasil 
penilaian supervisi akademik untuk setiap Guru. Rekapitulasi hasil supervisi akademik setiap aspek dapat dilihat pada Tabel 4.3 .berikut ini.

Tabel 3. Rekapitulasi hasil supervisi akademik setiap aspek pada Siklus I dan Siklus II

\begin{tabular}{|c|c|c|c|c|}
\hline \multirow{2}{*}{ No. } & \multirow{2}{*}{ Aspek } & \multicolumn{2}{|c|}{ Prosentase Ketercapaian } & \multirow{2}{*}{ Peningkatar } \\
\hline & & Siklus I & Siklus II & \\
\hline 1 & Persiapan & 47 & 97 & 50 \\
\hline 2 & Apersepsi & 39 & 96 & 57 \\
\hline 3 & Tujuan pembelajaran & 41 & 90 & 49 \\
\hline 4 & Penguasaan materi & 78 & 89 & 11 \\
\hline 5 & Strategi Belajar & 60 & 81 & 21 \\
\hline 6 & Metode & 65 & 85 & 20 \\
\hline 7 & Media & 54 & 97 & 43 \\
\hline 8 & Manajemen kelas & 54 & 88 & 34 \\
\hline 9 & Pemberian motivasi & 56 & 77 & 21 \\
\hline 10 & Nada dan Suara & 56 & 81 & 25 \\
\hline 11 & Penggunaan Bahasa & 59 & 64 & 5 \\
\hline 12 & Gaya dan Sikap Perilaku & 59 & 71 & 12 \\
\hline & Rata - rata & 56 & 85 & 29 \\
\hline
\end{tabular}

Hasil penilaian supervisi akademik untuk setiap Guru dapat dilihat pada tabel 4 berikut ini.

Tabel 4. Rekapitulasi hasil penilaian supervisi akademik untuk setiap Guru

\begin{tabular}{|c|c|c|c|}
\hline \multirow{2}{*}{ No. } & \multirow{2}{*}{ Kode Guru } & \multicolumn{2}{|c|}{ Nilai Supervisi Akademis } \\
\hline & & Siklus I & Siklus II \\
\hline 1. & GR-01 & 67 & 87 \\
\hline 2. & GR-02 & 67 & 85 \\
\hline 3. & GR-03 & 67 & 85 \\
\hline 4. & GR-04 & 52 & 78 \\
\hline 5. & GR-05 & 56 & 80 \\
\hline 6. & GR-06 & 67 & 81 \\
\hline 7. & GR-07 & 60 & 82 \\
\hline 8. & GR-08 & 60 & 83 \\
\hline 9. & GR-09 & 67 & 87 \\
\hline 10. & GR-10 & 54 & 80 \\
\hline 11. & GR-11 & 64 & 83 \\
\hline & Rata-Rata & 62 & 83 \\
\hline
\end{tabular}

\section{Pembahasan}

Diskripsi kondisi awal kompetensi Guru dalam menyusun RPP Peneliti peroleh berdasarkan hasil wawancara dan penilian RPP yang sudah dibuat Guru. Berdasarkan hasil wawancara yang disajikan pada Tabel 1 dapat dikatakan bahwa semua guru belum mengetahui pedoman yang digunakan untuk menyusun RPP dan kerangka penyusunan RPP. RPP yang digunakan untuk pelaksanaan pembelajaran sebagian besar mengadopsi RPP yang dibuat oleh MGMP. Guru hanya mengganti pada bagian Nama Sekolah, nama Kepala Sekolah, nama Guru Mapel, tempat tanggal. Setelah melakukan wawancara kepada semua Guru, Peneliti melakukan penilaian penyusunan RPP yang sudah dibuat sebelum penelitian ini dilaksanakan. Berdasarkan 
Tabel 2 pada kondisi awal menunjukkan bahwa prosentase ketercapaian komponen-komponen RPP sebesar 52\%. Kompetensi guru dalam menyusun RPP termasuk dalam kategori kurang artinya RPP yang disusun oleh Guru baru mencakup separo dari komponen-komponen RPP yang seharusnya. Beberapa komponen yang sudah baik meliputi identitas, standar kompoetensi dan kompotensi dasar. Komponen-komponen pokok seperti Indikator pencapaian kompetensi, tujuan pembelajaran, materi, langka-langkah pembelajaran, metode dan penilaian belum sesuai dengan aspek yang dikehendaki. Analisa hasil wawancara dan penilaian RPP ini Peneliti gunakan sebagai dasar untuk melaksanakan sosialisasi supervisi kepada Guru. Sosialisasi supervisi meliputi regulasi RPP, kerangka RPP dan menyusun RPP yang baik dan benar. Peneliti juga melaksanakan pendampingan secara intensif atau bimbingan berkelanjutan. Bimbingan berkelanjutan diberikan secara personal maupun kelompok. Bimbingan dilaksanakan supaya Guru dapat meningkatkan kompetensi dalam menyusun RPP dan pelaksanaan pembelajaran secara optimal. Hal ini sesuai dengan teori yang dikemukakan oleh Glickman, at al (2007) bahwa satu di antara tugas kepala sekolah adalah melaksanakan supervisi akademik. Untuk melaksanakan supervisi akademik secara efektif diperlukan keterampilan konseptual, interpersonal dan teknikal. Teknik-teknik supervisi akademik meliputi dua macam, yaitu: individual dan kelompok (Gwyn, 1961). Sosialisasi dan pendampingan yang Peneliti laksanakan mendapat respon positif dari Guru. Hal ini ditunjukkan melalui sikap yang baik dan tumbuhkembangnya motivasi dalam menyusun RPP.

Kompetensi guru dalam menyusun RPP setelah adanya pendampingan intensif pada Siklus I menunjukkan peningkatan yang cukup menggembirakan. Berdasarkan Tabel 2 menunjukkan bahwa prosentase ketercapaian kompetensi guru dalam menyusun RPP sebesar 69\% termasuk dalam kategori baik. Prosentase ketercapaian pada komponen Identitas mata pelajaran, Standar kompetensi, Kompetensi dasar, Tujuan pembelajaran, Alokasi waktu, Metode pembelajaran, Sumber belajar minimal 66\% ternasuk dalam kategori baik. Artinya Guru lebih memahami dan mengetahui komponen-komponen dalam penyusunan RPP. Sedangkan pada komponen Indikator, Materi ajar, Langkah-langkah pembelajaran, Penilaiaan hasil belajar prosentasi ketercapaian maksimal sebesar $61 \%$ termasuk dalam kategori kurang. Meskipun demikian, pencapain ini lebih baik dari Kondisi Awal. Peningkatan kompetensi Guru melalui pendampingan juga telah diteliti oleh Shodik (2018). Hasil penelitiannya menunjukkan bahwa melalui kegiatan pendampingan dapat meningkatkan kemampuan Guru dalam pembelajaran. Hasil penelitian yang dilaksanakan oleh Sari (2016) menunjukkan bahwa melalui kegiatan pendampingan berkelanjutan dapat meningkatkan kemampuan guru dalam menyusun RPP dan melaksanakan pembelajaran.

Selanjutnya Peneliti melaksankan supervisi akademik yaitu melakukan pengamatan pelaksanaan pembelajaran Siklus I. RPP yang digunakan adalah RPP yang dibuat pada Siklus I. Hasil supervisi akademik yang ditunjukkan dalam Tabel 3 ditermukan bahwa Guru belum mampu melaksanakan pembelajaran sesuai dengan aspek-aspek yang diharapkan. Skor prosentase ketercapaian aspek pelaksanaan pembelajaran sebesar 56\% termasuk dalam kategori kurang. Berdasarkan pengamatan ditemukan bahwa Guru hanya unggul dalam aspek penguasaan materi, tetapi masih lemah dalam mencapai aspek-aspek lainnya. Berdasarkan Tabel 4.4 menujukkan bahwa kompetensi Guru dalam melaksanakan pembelajaran sebesar $62 \%$ termasuk dalam kategori cukup. Ini berarti bahwa Guru menguasai sebagian dari aspek pelaksanaan pembelajaran berdasarkan RPP yang telah disusunnya. Berdasarkan hasil supervisi pada Siklus I, Peneliti memberikan umpan balik dan pembimbingan yang difokuskan pada komponen-komponen yang belum sesuai harapan. Guru melakukan perbaikan dalam menyusun RPP. Hasil pembimbingan berkelanjutan digunakan sebagai pedoman Guru untuk menyusun RPP dan pelaksanaan pembelajaran pada Siklus II.

Pada Siklus II diperoleh hasil supervisi ketercapaian kompetensi Guru dalam menyusun RPP sebesar $83 \%$ termasuk dalam kategori baik sekali. Hasil ini menujukkan bahwa Guru sudah memahami dan mengetahui semua komponen-komponen dalam menyusun RPP. Pada komponen sumber belajar menunjukkan hasil terendah yaitu $70 \%$ termasuk kategori baik. 
Sebagian besar Guru hanya menggunakan satu jenis sumber belajar yaitu dalam bentuk buku. hanya sebagian kecil Guru menggunakan sumber belajar jenis lain seperti power point, website, internet. Hasil supervisi akademik pelaksanaan pembelajaran pada Siklus II berdasarkan Tabel 3 menunjukkan prosentase ketercapaian aspek-aspek pembelajaran sebesar $85 \%$ ternasuk dalam kategori baik sekali. Artinya Guru mahir dalam melaksanakan pembelajaran. Berdasarkan Tabel 4 menujukkan bahwa kompetensi Guru dalam melaksanakan pembelajaran sebesar 83\% termasuk dalam kategori baik sekali. Ini berarti bahwa Guru menguasai semua aspek pelaksanaan pembelajaran. Peningkatan kompetensi guru melalui supervisi akademik telah diteliti oleh Erfy (2019). Hasil penelitiannya menunjukkan bahwa Supervisi akademik dapat membantu guru untuk mempelajari dan memahami tugas dan perannya sebagai seorang pendidik. Hasil penelitian yang dilakukan oleh Erni (2017) menunjukkan bahwa supervisi akademik kepala sekolah berpengaruh secara signifikan terhadap profesionalisme guru.

Berdasarkan hasil penelitian secara keseluruhan menujukkan bahwa supervisi dan pendampingan intensif menunjukkan hasil yang menggembirakan. Peningkatan kompetensi Guru dalam menyusun RPP berdasarkan hasil supervisi ketercapaian komponen-komponen RPP setiap skor dan prosentase ketercapaian pada kondisi awal, Siklus I dan Siklus II yang ditunjukkan pada Grafik 1 nampak bahwa terjadi penurunan pada skor rendah yaitu skor 1 dan 2. Sebaliknya terjadi peningkatan pada skor tinggi yaitu 3 dan 4 . Pada kondisi awal jumlah skor 1 (S1-0) sama dengan 6 atau 4,96\% dan mengalami penurunan menjadi 0\% pada Siklus II (S1II). Untuk Skor 2 pada kondisi awal 18,18\% (S2-0) turun menjadi 3,31\% pada Siklus II (S2-II). Penurunan skor 1 dan 2 memberikan dampak positif terhadap kompetensi Guru dalam menyusun RPP. Berdasarkan Grafik 1.1 pada kondisi awal ditemukan bahwa belum semua Guru menyusun RPP. Hal ini ditunjukkan oleh prosentase total skor ketercapain untuk semua kompunen pada kondisi awal 73\%. Pada Siklus I dan Siklus II menunjukkan total skor 100\% artinya bahwa setelah dilakukukan pendampingan dan supervisi semua Guru sudah memyusun RPP. Hasil supervisi perangkat RPP menunjukkan adanya peningkatan pemahaman guru tentang komponen-komponen RPP yang digunakan. Pada kondisi awal prosentase ketercapaian komponen RPP sebesar 52\%. mengalami peningkatan pada Siklus I menjadi 69\% dan Siklus II menjadi $85 \%$. Hasil supervisi akademik pada siklus I pencapaian aspek pelaksanaan pembelajaran sebesar 56\% dan rata-rata nilai yang diperoleh Guru sebesar 62. Pada Siklus II pencapaian aspek pembelajaran menjadi 84,67 dan rata-rata nilai yang diperoleh Guru sebesar 83. Hasil yang diperoleh sampai dengan Siklus II menunjukkan tercapainya tujuan penelitian yaitu semua Guru meyusun RPP, Prosentase skor total ketercapaian komponen-komponen RPP minimal 80\% dan kategori minimal baik untuk setiap komponen RPP.

\section{KESIMPULAN}

Keberhasilan pendidikan ditentukan oleh kinerja Guru yang baik. Proses pengembangan kinerja guru terbentuk dan terjadi dalam kegiatan belajar mengajar. Guru harus mempersiapkan perencanaan pembelajaran dan segala sesuatu agar proses pembelajaran efektif. Perencanaan pembelajaran merupakan langkah yang sangat penting sebelum pelaksanaan pembelajaran. Perencanaan yang matang diperlukan supaya pelaksanaan pembelajaran berjalan secara aktif, inovatif, kreatif, efektif dan menyenangkan. Perencanaan pembelajaran dituangkan ke dalam Rencana Pelaksanaan Pembelajaran. RPP memuat kompetensi inti, kompetensi dasar, indikator pencapaian kompetensi, materi yang akan dipelajari, metode pembelajaran, langkah-langkah pembelajaran, media pembelajaran, dan sumber belajar serta penilaian. Guru harus mampu melaksanakan tugas dan fungsinya secara optimal dan profesional. Guru wajib memiliki kualifikasi akademik dan kompetensi untuk mewujudkan tujuan pendidikan yang bermuara pada tercapainya tujuan Pendidikan Nasional.

Berdasarkan hasil analisa dan pembahasan dari hasil Penelitian Tindakan Sekolah dapat disimpulkan bahwa kompetensi Guru dalam menyusun RPP dapat ditingkatkan melalui Supervisi dan pendampingan intensif. Keberhasilan Penelitian Tindakan Sekolah ditunjukkan dengan: 1) peningkatan Guru yang menyusun RPP yaitu dari $73 \%$ pada kondisi awal menjadi 
100\% pada Siklus I dan Siklus II (mencapai kriteria indikator keberhasilan penelitian yaitu $100 \%$ ), 2) peningkatan nilai rata-rata kesesuaian komponen-komponen (prosentase ketercapaian) RPP. Pada kondisi awal penelitian prosentase ketercapaian komponen-komponen RPP sebesar 52\%. Pada Siklus I meningkat menjadi 69\% dan pada Siklus II meningkat menjadi $83 \%$ (melampaui kriteria indikator keberhasilan penelitian yaitu 80\%), 3) pada Siklus II prosentase ketercapaian untuk setiap komponen RPP minimal dalam kategori baik (mencapai kriteria indikator keberhasilan penelitian yaitu minimal baik). Peningkatan kompetensi Guru dalam menyusun RPP nampak juga adanya peningkatan kemampuan Guru dalam pelaksanaan pembelajaran. Peningkatan ini ditunjukkan dengan rata-rata prosentase pencapaian aspek pembelajaran pada Siklus I sebesar 56\% menjadi 85\% pada Siklus II. Rata-rata nilai supervisi akademik Guru pada Siklus I sebesar 62 menjadi 83 pada Siklus II.

Penelitian ini telah membuktikan bahwa Supervisi dan pendampingan intensif dapat meningkatkan kemampuan Guru dalam menyusun Rencana Pelaksanaan Pembelajaran. Oleh karena itu Peneliti memberikan saran: 1) untuk Kepala Sekolah diharapkan melaksanakan Supervisi minimal satu kali pada setiap semester dan pendampingan secara berkelanjutan. Hasil supervisi digunakan sebagai pedoman untuk melaksanakan pembimbingan secara individu atau personal. 2) Sekolah melaksanakan pembimbingan melalui pelatihan penyusunan RPP minimal satu tahun sekali, 3) untuk Guru diharapkan mengetahui pedoman penyusunan RPP dan kerangka RPP, 4) RPP yang disusun hendaknya tidak hanya mengadopsi dari sumber lain, melainkan juga melakukan revisi RPP dan disesuaikan dengan kondisi Sekolah, Guru dan siswa yang diajar.

\section{DAFTAR PUSTAKA}

Alfiah. (2016). Peningkatan Kemampuan Guru Menyususn RPP Melalui Pendampingan Berkelanjutan. Jurnal Penelitian Pendidikan Indonesia Vol 1, No 2 (2016). http://irpp.com/index.php/jpp/article/view/366

Ali, M. (2017). Peningkatan Kemampuan Guru Dalam Menyusun Rencana Pelaksanaan Pembelajaran (RPP) Melalui Supervisi Akademik. Jurnal Ilmu Pengetahuan Sosial, 3 (1).

Depdiknas Tahun 2005, tentang Standar Nasional Pendidikan. Jakarta: Depdiknas.

Depdiknas Tahun 2008, tentang Perangkat Pembelajaran Kurikulum Tingkat Satuan Pembelajaran SMA. Jakarta.

Erfy, M.L. (2019). Implementasi Supervisi Akademik untuk Meningkatkan Mutu Guru. Universitas Kristen Wira Wacana Sumba : Indonesia. https://journal.uny.ac.id/index.php/jamp/article/view/22276

Erni, A.S. (2017). Supervisi Akademik Kepala Sekolah, Profesionalisme Guru dan Mutu Pendidikan. Jurnal Administrasi Pendidikan, Vol. 24 No.2 (2017). https://ejournal.upi.edu/index.php/JAPSPs/article/view/8294

Glickman, C.D., Gordon, S.P., and Ross-Gordon, J. M. (2007). Supervision and Instructional Leadership A Development Approach. Boston: Perason.

Gwynn, J. (1961). Theory and Practice of Supervision. New York: Dodd, Mead \& Company.

Pidarta, Made .(1992). Pemikiran Tentang Supervisi Pendidikan. Jakarta: Bumi Aksara.

Shodik. (2018). Peningkatan Kemampuan Guru dalam Pembelajaran Berbasis ICT Melalui Kegiatan Pendampingan Guru-Guru SDN Kalongan 03 Kecamatan Ungaran Timur Kabupaten Semarang Semester 1 Tahun Pelajaran 2017/2018. https://jurnal.fkip.uns.ac.id/index.php/diksar/article/download/12122/8636

Syamsuddin, Hs. (2019). Penerapan Supervisi Akademik untuk Meningkatkan Kinerja Guru. Jurnal Imiah Pendidikan dan Pembelajaran p-ISSN : 1858-4543 e-ISSN : 2615-6091 JIPP, Volume 3 Nomor 2 (2019).

UU RI Tahun 2003 No. 20, tentang Sistem Pendidikan Nasional. Jakarta: Depdiknas.

UU RI Tahun 2005 No. 14, tentang Guru dan Dosen. Jakarta: Depdiknas 